\title{
Correspondence
}

\section{Review boards: all need closer scrutiny}

As director of a consulting group that works with institutional review boards (IRBs) at universities, hospitals and commercial organizations in the United States, I disagree that commercial IRBs are unduly influenced by profits and are less thorough than their academic counterparts (Nature 476, 125; 2011).

Many of the IRBs enveloped in your critique are accredited by the Association for the Accreditation of Human Research Protection Programs (AAHRPP). The two IRBs censured by the US Food and Drug Administration, Essex and Coast, were not. AAHRPP accreditation is voluntary; organizations undergo a rigorous assessment of their policies and records, including on-site interviews to ensure compliance with federal regulations and AAHRPP standards.

For accreditation, IRBs must separate business decisions from ethical review, even though this is not federally mandated. For instance, independent IRBs accredited by the AAHRPP prohibit equity holders from serving as IRB members or participating in research review. Independent IRBs are constantly evaluated by sponsors, clinical research organizations, regulators and the AAHRPP. Profit is often reinvested in training in ethics and regulatory processes for IRB members and staff.

Absent from your Editorial was an acknowledgement that universities and hospitals can have a proprietary interest in their research; independent IRBs do not. I believe that additional scrutiny of all IRBs is needed: protecting human subjects in research overseen by a hospital or university IRB is just as important as protecting those in research reviewed by independent IRBs.

Nicholas C. Slack HRP

Consulting Group, Rockville, Maryland, USA.slackn@ thehrpconsultinggroup.com
Competing financial interests declared. See go.nature.com/ m5qaue.

\section{South Korean energy plan is unrealistic}

South Korea imports $97 \%$ of its energy and is the world's tenthlargest emitter of greenhouse gases. It has increased its target for supplying renewable energy from $2.4 \%$ in 2008 to $6.1 \%$ by 2020 . This seems overly ambitious, given that its renewable energy has increased by only $0.37 \%$ in the past decade. Even that aim is modest compared with the European Union's goal to source $20 \%$ of its energy from renewables by 2020.

South Korea is attempting to transform from quantitative to low-carbon qualitative growth (Nature 464, 832-833; 2010). This green-growth strategy encourages policies that tackle climate change and enhance security, and aims to create new markets by investing $2 \%$ of gross domestic product in renewable-energy sources over the next five years.

These measures are unrealistic, however, given the state of the South Korean newand renewable-energy industry. Even with an export boom, the country's lack of original technology and facilities could result in profits going overseas. The problem lies with South Korea's high dependence on imports of core components for export goods, combined with its sluggish rate of change to domestic production.

Scientists must agree on which new- and renewableenergy technologies are suitable for adoption. They need to take into account economic factors, convenience, safety and reliability, and to convince industry and consumers to recognize the advantages. Hyung-Man Kim Inje University, Gimhae, South Gyeongsang, South Korea. mechkhm@inje.ac.kr

\section{NATURE'SREADERS COMMENT ONLINE}

A taste of the lively discussion on working 24/7

(Nature 477, 5, 20-22 and 27-28; 2011).

Kausik Datta says:

Hard work is essential, but most major scientific discoveries are arrived at by serendipity, the appreciation of which requires creativity and a thinking, enlightened mind. A slave-driving mentorship that encourages drone-like devotion to work and assembly-line productivity will only result in early burn out and the loss of love for science.

kdatta1@jhmi.edu

Jessica Mark Welch says: Science demands hard work, but to sacrifice your health and your family life, so that while nominally spending time with your kids you are on the phone with your lab? How unreconstructed. I do not want a world where only people who can live that way can be scientists. jmarkwelch@mbl.edu

\section{Burkhard Haefner says:}

All of us need time to relax and think or even to dream - to let the soul dangle, as we say in German. We all know the story of Isaac Newton wasting away his time, or so it seemed, lying under an apple tree.

bhaefner@its.jnj.com

\section{Dean Griffiths says:}

Rarely do insights occur after 14 hours of picking colonies. While it may be great for a PI [principal investigator] to publish lots of mediocre papers, students and postdocs require big papers to become established - and constantly working insane hours is unlikely to achieve this. Plus there really are times with your family that you can never get back. Is it worth missing them to do another PCR? dsg29@cam.ac.uk

Maya Capelson says: An average life scientist in the lab, grad student or postdoc, working 50-60 hours per week, will probably produce at least one paper in 4-5 years. Twentyseven people working over 100 hours a week [in the lab profiled] produce just 29 papers in 5-6 years. So pretty much the same productivity as a scientist working for only half that time. capelson@salk.edu

Chris Wood says:

I respect Alfredo QuiñonesHinojosa for his honesty and the fact that he screens out his applicants to ensure they fully realize what they are getting into. And if they cannot stay the pace, he supports them in transferring somewhere more appropriate. chris@ibt.unam.mx

Srikrishna Pandey says: Some researchers and engineers really enjoy their work, so when they have to work overtime it doesn't occur to them to resent it. srikrishnapandey@gmail.com

Julien Marquis says: Some Pls may never have experienced the devastation of trashing a year's work. It is important and even pleasant to work very hard, but not always and not on anything. So Pls - if you want your crew (particularly naive $\mathrm{PhD}$ students) to work hard, ensure that they are pursuing a promising track. julien.marquis@epfl.ch

To join this debate, go to go.nature.com/djydhr. 